\title{
An unconventional interpretation on periodization and dimensions of globalization in historical perspective
}

\author{
Alexandre Ottoni Teatini Salles*
}

\begin{abstract}
Resumo
Ao contrário dos ciclos econômicos de curto prazo, o fenômeno da globalização tem se desenvolvido em ondas longas,marcado por períodos de auges e crises. A globalização é geralmente definida como um processo de integração das economias nacionais em esfera global, envolvendo mercados produtivos e financeiros. A maior utilização do termo nas últimas décadas não significa que o fenômeno é novo. Assim, o objetivo do artigo é analisar as pré-condições, periodização e dimensões da globalização numa perspectiva histórica. Muitos estudiosos têm discutido suas causas e consequências com base no que ocorreu nas últimas décadas, normalmente começando no final dos anos 1970.Contudo, o fenômeno tem precedentes históricos, ou seja, não é uma ocorrência exclusiva do capitalismo do final do século XX. Há uma literatura sendo escrita sobre o assunto sugerindo que a ocorrência de uma maior conectividade internacional envolve muitas áreas da atividade humana ocorreu há muitos séculos atrás. $\mathrm{O}$ artigo então postula que a globalização não é apenas secular, mas sim um fenômeno milenar. Assim, propõe que aspectos não-econômicos da integração global devem ser considerados como elementos-chave para o entendimento do tema, e que estes têm sido negligenciadas por economistas e historiadores econômicos. Conclui-se que o início das primeiras ocorrências históricas da globalização ocorreu ainda na Idade Média, e enfatiza a importância de aspectos extra econômicos tais como cultura e a linguagem.
\end{abstract}

Palavras-chave: eras da globalização, história, cultura e linguagem

JEL: F00; O10; O47

\section{Introduction}

The increased occurrence of speculative bubbles and the spread of financial crises(especially from the 1990s) have more and more stimulated the interest of scholars from within and outside economics to the study of globalization. Historically speaking, it does not progress smoothly from one era to the next, but, unlike the short-term business cycles, it has developing in long waves surrounded by periods of booms and different types of

\footnotetext{
*Departamento de Economia, Programa de Pós Graduação em Economia da Universidade Federal do Espírito Santo, E-mail: aotsalles@gmail.com
} 
crises. The phenomenon is usually associated with a process economic integration across national borders into a wider (global) sphere involving their productive and financial markets.

The current increased use of the term does not mean that the phenomenon is actually new. Many scholars have discussed its causes and consequences based on what has been taking place in global integration from the last few decades, normally starting in the late 1970s. Nevertheless, the phenomenon has precedents in history, i.e., it is not an exclusive occurrence of the late 20th century capitalism. A literature has flourished suggesting that the occurrence of greater global connectivity involving many areas of human activity and social interaction has occurred at times in history since a century (or even centuries) ago. It draws attention to the fact that international integration in historical perspective is not only secular but an ancient phenomenon. Hence, globalization has varied significantly, shaping a non-linear historical process, and thus receiving different taxonomies and depictions.

As a matter of fact, the debate on globalization has been much wider and more multifaceted than discussed within economics. That means, its causes and effects are not only confined to economic aspects but also involve many different features combining political, institutional, cultural, ecological, technological, spatial and sociological dimensions. Evoking these and other characteristics, it has therefore become a multidimensional theme and an interdisciplinary topic within academia.

As a multidimensional subject, the phenomenon implies multiple associations, accepting contributions from different areas. Clearly, it is out of the scope of this article to scrutinise all these aspects. The central point to be discussed is the proposition that globalization is an age-old phenomenon, unlike the conventional approach proposed by most economists and economic historians. Therefore, it postulates that non-economic aspects of global integration should be considered as key elements to survey the topic. Globalization is considered here a historical phenomenon determined by the existence of various forms of human interaction between nations. So, apart from economics, it is understood as being result of social and political actions and relations, spurred by the mutual influence of countries.In the literature, these aspects have been neglected by leading scholars.

To establish these points, the next section discusses what globalization mean within economics, addressing contributions from researchers with different backgrounds. Based on Held et al (1999) proposition, the third presents a historical periodization that differs from what is advocated by most academics in economics. Section four surveys some core dimensions of globalization outside economics, namely, technology, law, nation-state, culture and language. Finally, the fifth concludes the essay. 


\section{Was does globalization mean within economics?}

Itis well known that there is no consensus amongst economists about the definition of the term (Scholte, 2002), so there will be no consensus also about when it started.This section aims to scrutinize the overview of influential scholars on key definitional aspects of globalization (among them, Joseph Stiglitz,Nobel Laureate in Economics in 2001). So then contributions from scholars with different backgrounds are welcomed, but it would be impossible to survey the existing literature dealing with it. There is a colossal amount of papers, books, etc on the subject, and it is beyond the scope of this section to revise it all. A swift review would suffice to identify the core preconditions of the phenomenon in economics.

Nevertheless, taking into account the approach of economists from different theoretical perspectives, it can be noticed the conventional interpretation of globalization within economics. Furthermore, the section addresses its definition as an invitation to scrutinize the mainstream understanding of its periodization, which can be summarized as follows: the phenomenon has its roots established in the twentieth century, or, at most, in the early days of capitalism, which differs from the proposition made in this article.

At least three aspects have been frequently included in the numerous definitions of globalization available in the current literature, namely: the possible causes, the scope, and the thickness of the phenomenon. The biggest disagreements and controversies on the subject are located in these points since they involve the subjective interpretation of what are the main driving forces behind it, and the impact of its transformations over the status quo ante.

Economists and other social scientists suggest that globalisation is defined as a process of growing integration of national economies tending to constitute a worldwide market for goods, services, labour and capital. In this way, Harris (1993:755) pointed out very accurately: "To economists globalization is generally thought of as the increasing internationalization of the production, distribution and marketing of goods and services." Thus, for many writers the phenomenon is most visible as a process of global commercial, productive, migrating or financial integration. It embodies a wide scope of markets and interconnection of national economies on an international scale caused by a range of policy, institutional, social and technological changes. More precisely, it encompasses the erosion of a number of tariff (or other institutional) barriers, the drop in transportation costs, technological improvements in telecommunications and microelectronics, and the development of new competitive strategies by banks, non-banking institutions and multinational corporations (outsourcing, maquiladoras, mergers and acquisitions for instance).

Furthermore, they have been emphasizing that economic policy, technological advances and institutional changes have been progressively overcoming the constraints of geography and gradually establishing a denser network of global linkages. The width of those changes may not be universal (Scholte, 2002:8) or homogeneous but transnational 
connections have been purposely established and have been changing economic, social and political international affairs. In a nutshell, globalization is usually associated with a process of the integration of national economies into a wider (global) sphere involving their productive and financial markets.

Michael Bordo has written scholarly papers touching on various aspects concerning the debate on globalization. Bordo (2002:20) proposed the following definition of it: "I define globalization as the increasingly close international integration of markets for goods, services and factors of production, labour and capital." He emphasised the role played by the WTO (GATT until December 1994) spurring the process of global integration through the continuous reduction of non-tariff barriers and protection, mainly since the post WWII period.1In general, his analysis is supported by extensive data focused on changes that have been occurring in world trade, foreign direct investment (FDI) and cross-border financial capital flows. Elsewhere, he has been expressing his concerns about the growing importance of financial markets as the key driving force of modern globalization (Bordo 2000, Bordo, Eichengreen and Irwin 1999).

Similarly, Nobel laureate Joseph Stiglitz (2002:9) states that globalization means the closer integration of countries and people, made possible by technological developments and institutional changes. In the passage below, he highlights the importance of actual and new institutions to the progression of contemporary global integration. In his words:

\begin{abstract}
Globalization is the closer integration of the countries and peoples of the world which has been brought about by enormous reduction of costs transportation and communication, and the breaking down of artificial barriers to the flows of goods, services, capital, knowledge, and (to a lesser extent) people across borders. Globalization has been accompanied by the creation of new institutions that have joined with existing ones to work across borders. ... Globalization is powerfully driven by international corporations, which move not only capital and goods across borders but also long-established international intergovernmental institutions (Italics original).
\end{abstract}

Stiglitz emphasises the role played by institutions, technological developments in various areas, and policy issues as important aspects driving forward the process of global integration. However, instead of integration, some scholars (Heldet al 1999) have used another term to illustrate different aspects of current globalization, which is enmeshment. The noun enmeshment comes from the verb enmesh used to describe a situation when someone or something is caught or entangled as in a net, and which is not easy to escape from. Applied to globalization, scholars prefer to use it instead of the general and arguably vague term integration because enmeshment involves the formation of a network that intertwines markets, institutions, companies, private agents, governments, contracts, agreements, etc, and all apparatus underlying the diverse dimensions of globalization.

Jeffrey Frankel (2000:2) highlighted the importance of technological and policy changes as core aspects of current globalisation. According to him, there are two major drivers of

Econômica-Niterói, v. 21, n. 1, p. 121-140. Junho, 2019 
economic globalisation in the post war period, which are associated with an international policy change: the reduced costs to transportation and communication in the private sector, and reduced policy barriers to trade and investment on the part of the public sector. The quotation below summarises the broad picture he painted to support his assertion. It is anenlightening historical depiction of key elements that spurred theprocess of global market integration between the first and the second half of the twentieth century.

\begin{abstract}
Technological progress and innovation have long been driving the costs of transportation and communication steadily lower. In the post-war period we have seen major further cost-saving advances, even within ocean shipping: supertankers, roll-on-roll-off ships, and containerized cargo. Between 1920 and 1990 the average ocean freight and port charges per short ton of U.S. import and export cargo fell from 95 to29 (in 1990 dollars). An increasing share of cargo goes by air. Between 1930 and 1990, average air transport revenue per passenger mile fell from $0.68 t o 0.11$. Jet air shipping and refrigeration have changed the status of goods that had previously been classified altogether as not tradable internationally. Now fresh-cut flowers, perishable broccoli and strawberries, live lobsters, and even ice cream are sent between continents.
\end{abstract}

Jan Kregel (1994) was one of the first voices amongst economists who proposed a notional concept of the progressive evolution of firms towards a global organisation. He identified three sequential prior stages that firms had passed to reach the "truly" globalised level. These stages are known as international, multinational and transnational.

The first stage occurred during the 1960s when foreign trade expanded faster than domestic output growth. In response, firms took advantage of the wide range of opportunities abroad, selling their marginal domestic product to foreign markets. This is what he called the internationalisation of markets. Then, the greater importance acquired by the exports to the development of the global economy, and also the formation of economic trade blocs such as the EEC, spurred firms on to the second stage of global integration. Therefore, firms moved from the international to the transnational arena. This means that, instead of increasing their exportations continuously, firms strategically decentralised the production process by building industrial plants in foreign markets. This decentralisation was meant to distribute "different stages of production to different national facilities to produce final products which are assembled and sold in specific targeted national markets" (Kregel 1994:30).

Finally, the period of globalisation is reached when firms have constituted an integrated and flexible process of production and distribution around the world. In Kregel's words (1994:30) 'the final step in the process of 'globalisation' comes as firms consider specific national markets as part of a single undifferentiated world or global market in which a single product line may be sold." More simply, transnational corporations have decentralised the final assembly process, spread it to different countries according to the 
availability of raw materials and semi-finished goods, and sold the output through an integrated global distribution system, reaching the world as a whole. In this stage, truly globalised transnational firms use "raw materials and half-finished goods from producers in a wide range of countries, with the final assembly process decentralized across a number of regional centres producing a unified product" (p. 30).

Kregel did not mention it explicitly in his 1994 piece, but these "regional centres" were inspired by the factories run by US companies (maquiladoras) in Mexico, but can also be the special economic zones (SEZ) founded in the early 1980s in China, which subsequently spread around the world. The creation of the WTO in 1995 played an important role in stimulating this process of corporate globalization. The reduction in tariffs imposed (sic) on developing countries reduced the costs and encouraged a wider integration of formerly dispersed production chains.

In short, Kregel (1994) defines globalisation as a gradual process of increasing global interconnection led by firms as an adaptive process of their competitive strategies to the historical changes that have taken place in the world economy. This adaptation determined the change in their scope in such a way that they can be considered the vehicle of globalisation.

Robert Keohaneand Joseph S. Nye Jr. (2000) suggested that at the turn of the millennium, the word globalization would replace the word interdependence, which was used to discuss matters of world politics during the 1980s and 1990s. They suggested that globalization and interdependence have many meanings and both concepts are meant to cover a variety of phenomena from economics to politics and so on. In fact, they disagree with the current usage within academia of the word "globalization". According to them, globalism is more appropriate because it means "a condition that can increase or decrease". Their definition of globalism is "a state of the world involving networks of interdependence at multicontinental distances." (Keohane and Nye, 2000, p. 105). In agreement, Giddens (2006, p. 50) also emphasises this reciprocal dependence as a salient characteristic that defines globalization. He states that "globalization refers to the fact that we all increasingly live in one world, so that individuals, groups and nations become interdependent."

David Held (2001, p. 427) describes globalization as a spatial phenomenon that interlinks communities and transforms core dimensions of human life such as power, criminal, financial and environmental.

Globalization is fundamentally a spatial phenomenon; it lies on a spectrum with the local and national at one end, and the (supranational) regional and global at the other. It is about the stretching of connections, relations and networks between human communities, an increase in the intensity of these, and a general speeding up of all these phenomena. Globalization denotes transcontinental or interregional flows and networks of activity, interaction and power. It is, in short, about the interconnections between different regions of the world - from the cul-

Econômica-Niterói, v. 21, n. 1, p. 121-140. Junho, 2019 
tural to the criminal, the financial to the environmental - and the ways in which they change over time.

According to Held, the phenomenon is not considered a process of adding previously isolated countries or regions into a larger space of interaction, formed and fed by the interface of numerous dimensions constituting a system. On this aspect, it applies the famous quotation from Aristotle, who stated that "the whole is greater than the sum of its parts." That means: globalization is greater than a geographic amalgamation of distant marketplaces. It is a process ("or a set of processes") in continuous transformation running across the spheres of human interaction, subject to the action of evolutive institutions, contradictions, advances and retreats. Besides to the productive, commercial and financial dimensions, its technological, political, cultural, military, environmental and legalistic aspects will be considered here.

In summary, the analysis on the preconditions of globalization based on the understanding of scholars from different perspectives reveals the conventional assessment of economists on its periodization. Conversely, the quotation above allows a different view. British political theoristDavid Held proposed to study it in terms of "relations between human communities and networks" and "from the cultural to the criminal, the financial to the environmental -and the ways in which they change over time" (emphasis added). This way, is it possible to trace an unconventional approach of its periodization. This is the purpose of the next section.

\section{An unconventional periodization of globalization in historical per- spective}

As mentioned above, the debate on globalization chronology is strongly related with the way scholars define it. If one had a general and unique definition of the term, its periodization would be probably general and unique too. However, as it was argued in the section above, there is a myriad of meanings, thus the debate on its chronological aspects also have several different interpretations.

Most scholars who address globalization from a historical perspective recognise three major starting points for the onset of the phenomenon: from the $15^{\text {th }}$ century; in the last quarter of the $19^{\text {th }}$ century; or from the last quarter of the $20^{\text {th }}$ century to date. Furthermore, Held et al (1999), Scholte (2001, 2002) and Robertson and Scholte (2007) (among others) have mentioned that some scholars also consider that the term globalization describes historical tendencies that can be traced back to ancient times even before the Middle Ages.

Norman Gall and Rubens Ricupero (1997) asserted that globalization started with the expansion of the European mercantilist system following the so-called Age of Discovery from the early $15^{\text {th }}$ century to the early $17^{\text {th }}$ century. According to them, starting in 
Western European countries, maritime expansion hailed the onset of a truly world economy since it promoted long-distance commercial linkages between Europe and several regional economic areas spread over all the continents. Those commercial routes, and the deep transformations in production, transport and communications they promoted characterised the beginning of the globalization era, which was consolidated in the $19^{\text {th }}$ century up to 1914 under Britain's economic and military dominance (so called Pax Britannica).

Contrasting with this view, K. O'Rourke and J. Willimanson (2002:24) found evidence of globalization in the 1820s in terms of trade price convergence. However, Bordo, Eichengreen and Irwin (1999:3) and Bordo (2002:21) asserted that the first age began circa 1870, encouraged by the British Gold Standard regime, and the second after the 1980 s, encouraged by the worldwide spread of liberalisation and deregulation policies, and spurred by the technological revolution in telecommunications systems. More precisely, Eichengreen and Bordo (2002:3) mentioned Charles Goodhart's viewpoint saying that the first age of globalization occurred when the transatlantic telegraph cable was laid between England and North America in 1866 because it revolutionised the intercontinental trade of assets. In their words: "Financial markets are markets in information; by speeding transatlantic communication, the advent of the cable in the 1860 s thus transformed their operation".

This is the general perspective that is largely found in the literature. Considering the alternative periodization sustained here about the ancient roots of globalization, two examples could be preliminarily mentioned to illustrate the phenomenon during this earlier period. First, one can recall the outstanding economic, political and social achievements of Alexander (Alexander the Great), king of Macedonia during the years 336-323 BC. He was the conqueror of Greek city-states and the Persian Empire from Asia Minor and Egypt to India. Likewise, Justinian I (Justinian the Great), Byzantine emperor during the 527-565 AD, extended the boundaries of the Greek-speaking Roman Empire of the Middle Ages far beyond its extension of that time.

The title the Great was awarded not only because of the extraordinary geographic expansion they promoted despite the logistic resources of the time, but also because the territorial increase of their empires introduced and encouraged important changes to overdistant areas in diverse aspects of human society. For example: overseas trade, civil law and judicial practices, administrative and political reforms, culture (especially in sciences, arts and language), religious practices anddoctrines, military tactics of conquest war, to name but a few of the most importantaspects. In fact, this could be one of the possible meanings related to globalization. Namely, a historical process of territorial expansion headed in general by one nation (followed by others afterwards), which end up promoting great transformations to a larger extent, spreading them out over long distances and to a wide range of aspects.And, eventually, changing societies from one state of affairs to another. This may be a more inclusive approach on globalization in historical perspective.

This seems to be the method proposed by Held et al (1999) in the book Global Trans- 
Table 1 - Chronology of historical forms of globalization

\begin{tabular}{|c|c|c|c|c|c|c|c|}
\hline Historcal forms of globalization & & & & & & & \\
\hline Periodisation & Political & Military & Financial & Production & Migration & Cultural & Environmental \\
\hline A) Pre-modern & & & & & & & \\
\hline 1) Pre-1500 & & & & & $\sqrt{ }$ & $\sqrt{ }$ & $\sqrt{ }$ \\
\hline B) Early modern, circa $1500-1850$ & & & & & & & \\
\hline 1) Early modern (14th-18th century) & $\sqrt{ }$ & $\sqrt{ }$ & & & & & \\
\hline 2) Early modern approx. $1500-1760$ & & & & $\sqrt{ }$ & $\sqrt{ }$ & & $\sqrt{ }$ \\
\hline 3) Early modern approx. $1500-1850$ & & & & & & $\sqrt{ }$ & \\
\hline 4) Early modern Pre-industrial Revolution & & & $\sqrt{ }$ & & & & \\
\hline C) Modern, circa 1850-1945 & & & & & & & \\
\hline 5) Modern (late 19 th-early 20 th century) & $\sqrt{ }$ & $\sqrt{ }$ & $\sqrt{ }$ & $\sqrt{ }$ & & & \\
\hline 6) Modern approx. 1760-1945 & & & & & $\sqrt{ }$ & & $\sqrt{ }$ \\
\hline 7) Modern approx, 1850-1945 & & & & & & $\sqrt{ }$ & \\
\hline D) Contemporary, 1945 to date & & & & & & & \\
\hline 1) Contemporary approx. 1945 on & $\sqrt{ }$ & $\sqrt{ }$ & & & $\sqrt{ }$ & $\sqrt{ }$ & $\sqrt{ }$ \\
\hline 2) Contemporary Bretton Woods period (1945 to 1973) & & & $\sqrt{ }$ & $\sqrt{ }$ & & & \\
\hline 3) Contemporary approx. 1973 on & & & $\sqrt{ }$ & $\sqrt{ }$ & & & \\
\hline
\end{tabular}

Source: Adapted from Held et al (1999:80, 135, 222, 272, 306, 364, 392).

formations, although they search the roots of the phenomenon through a historical inquiry that dates back many years before the two examples mentioned above. The authors extensively studied the chronology of globalization and distinguished seven historical forms of the phenomenon divided into four subsequent eras. The eight chapters of the book are dedicated to presenting in great detail the main characteristics of these different forms of globalization, hence it is impossible to make an outline of the arguments developed by them within the scope of this section. However, since it is a unique contribution to the debate, table 1 shows synthetically the historical division they proposed and it is followed by a summary of the main characteristics of each phase.

Looking at the table above, it may be noted that Held et al (1999) believe that the beginning of the first historical occurrences of globalization occurred much earlier than was proposed by the authors studied in the second section of this article. They propose that globalization is not a one-century phenomenon but a historical process that has been progressively disclosed in diverse forms throughout history. Therefore, there is not one but various forms of globalization that change over time. They selected the most salient characteristics in each period and demonstrated how the development of human relations promoted an increasing enmeshment of economic, social, cultural, military, environmental and political activities across countries. In this way, they explain the emergence of various periods of globalization based on the study of human interaction since ancient times.

As presented in the table above, the authors proposed a fourfold periodization of globalization: pre-modern (pre-1500), early modern (circa 1500-1850), modern (circa 18501945) and contemporary (1945 to date). Each form of globalization reflects the spatiotemporal and human conditions of the time. The first form lasted thousands of years since human interaction and the emergence of any long distance activity was severely restricted by the limited technology of transport and communication. As a result of the development 
of adequate knowledge and equipment, the transformation process became faster, more intense and with greater scope.

The pre-modern period began with the formation of agrarian centres in Eurasia, Africa and the Americas around 9,000 to 11,000 years ago. Without a doubt, the targets of the global interactions and consequently the social and infrastructural transformations were strictly limited by the technology available. The main characteristics of this age were interregional or inter-civilizational encounters within Eurasia since Oceania and the Americas remained autonomous civilisations. The key sources of globalization at this time were political and military empires, world religions and the migratory movements of both nomadic people and farming societies. Due to transport limitations, long distance trade between regions and civilizations was less intensive. Political, military or cultural interaction was far more difficult to establish, hence this era is described as a form of "thin globalization". During the early modern era, the phenomenon progressed motivated mainly by the European ultramarine conquests and the demographic, environmental and epidemiological flows between Europe, the Americas and Oceania. European innovation and expansion resulted more from the importation and adaptation of Eurasian technologies than on the development of indigenous innovations. European expansion in this era was not truly global but was significantly located in the Americas and Oceania. Political and military relationships and the formation of European global empires reinforced the channels of interconnection between continents. In addition, great trading companies related to the new empires (British East India Company, Hudson Bay Company and British Royal Africa Company) gave birth to new forms of economic globalization.

This modern period marked the onset of industrialisation and the enormous progress of military weapons, naval technologies and increasingly powerful state institutions. Accordingly, the intensity of intercontinental relationships increased significantly in terms of trade, investment and human migration. During the era, European power stretched to almost all areas of the globe.

Finally, Held et al consider contemporary globalization as a distinctive historical form of the phenomenon in terms of economics, politics, law, governance, military affairs, cultural linkages and human threats. They asserted that: "This era has experienced extraordinary innovations in the infrastructures of transport and communication, and an unparalleled density of institutions of global governance and regulation" (Held et al 1999, p. 425). The contemporary era represents a historically unique confluence of certain key aspects, such as, the Bretton Woods collapse in the early 1970s, the OPEC oil crises, the flow of petrodollars into international banking institutions, combined with new telecommunications infrastructures and a global wave of neoliberal deregulation from the 1980s onwards. These factors encouraged a surge in global trade, investment and financial flows especially between North America, Western Europe and Asia. 


\section{Core dimensions of globalization outside economics: language, tech- nology, law and nation-state.}

Up to this point, one can realize that globalization is not simply an amalgamation of markets or countries, but a process of ongoing intercontinental enmeshment of people. As a consequence, it has been transforming culture, language, habits and traditions, as well as changing the world in many other dimensions, such as geography, politics, economic, legal systems, firms, corporations, and technology. In this sense, globalization is an institutionalised concept. Its dynamic historical progress involves institutions in general and its evolution once it has been altering many areas of human life. In this sense, Perraton (2003:38) pointed out:

\footnotetext{
Globalization can be conceived as a process, or a set of processes, which embodies a transformation in the spatial organisation of social relations engendering a shift in the spatial reach of network and systems of social relations to transcontinental patterns of human organisation, activity and the exercise of social power.
}

In 1951, American Sociologist Paul Meadows mentioned the word globalization (p. 11) within inverted commas, with the same meaning with which it is used currently. This article arguably could be considered a seminal paper which, on sociological grounds, reveals key insightful thoughts relating globalization to the culture of the modern industrial society. For obvious reasons, he does not provide a scientific analysis of globalization in the current terms, nor does he develop the concept per se, but puts forward a basis of a debate about the tendency towards cultural universalization in the context of the advent of modern industrial technological societies. According to him, the tendency had been stronger than a cultural localisation. In Meadows's (1951:11) words: "with industrialism, a new culture system has evolved in one national society after another; its global spread is incipient and cuts across every local ethos." As this tendency is supposed to evolve over time, he concludes that this new culture pattern is in the process of "globalization," which is "replacing the central mythos of the medieval Church."

Language plays a key role in the globalization of culture, now and then. In this sense, it is worth mentioning that during the Alexander Age, the role of the Greek language was an important element of integration, very similar to English today. From Alexander, the Greek became the common language of the elite. It never replaced the local languages, but became the tongue used in trade relations among countries and in the "international relations".

However, during the Medieval Period, the Roman Empire urged the greater geographical integration directed by a single political center. The construction of roads, the creation of a postal system, the increase of navigations, and the establishment of a single currency, were key factors that accelerated the countries' integration at the time. All this was ac- 
complished through the use of Greek (in the eastern part) and Latin (in the western part) (Vlassopoulos, 2007, 2009).

In modern terms, English is the predominant world language. In certain aspects such as music, films and science, it have been widely spread around the world, influencing (not eliminating) these cultural activities in many countries. For similar reasons to those of ancient times, English became the world language primarily as a result of colonisation and the huge British Empire both in the Indian sub-continent and Africa. In those days, French was the language used in the diplomatic service but became marginalised by the growth of English over the years.

Although both France and Germany were themselves colonists, their Empires in the late 19th and early 20th century were not as widespread as that of Britain, particularly in Africa. These areas used English not only as their second language, but also their first language or common language. That happened because of the numerous languages/dialects spoken, so that the only language common to all was English. After WWII, the US became a great power, spreading its culture to Latin America and also to South East Asia because of their involvement in the war. Of course, there are more Chinese speakers in the world than speakers of other languages, but China has never played such an economically and politically significant role in world affairs as Britain did before WWI and the US has been playing since WWII, although the country is losing this condition after the deleterious effects of the 2008 crisis.

Moreover, English has become the common language through which scientists from many disciplines have chosen to communicate their thoughts, achievements and criticisms. Therefore, nowadays, English-language journals and books are preferred as a vehicle for exchanging scientific knowledge.

The data presented below is evidence of the point made above. The British Linguist David Crystal has researched the rise of English as a global language since the end of WWII. Crystal (2003:111) presents evidence to the fact that English is currently a global medium of communication of the world's scientific knowledge, especially in areas such as science and technology. More research could provide the same evidence in economics but there is no reason to think that the picture described below is much different or less significant in economics or in most other social science fields.

A 1980 study of the use of English in scientific periodicals showed that 85 per cent of papers in Biology and physics were written in English at that time, whereas medical papers were same way behind ( 73 per cent), and papers in mathematics and chemistry further behind still (69 per cent and 67 per cent) respectively. However, all these areas had shown a significant increase in their use of English during the preceding fifteen years - over 30 per cent, in the case of chemistry, and over 40 per cent, in the case of medicine - and the figures twenty years further on would certainly be much higher. This can be seen even in a language-sensitive subject such as linguistics, where in 1995 nearly 95 per cent of the 
1,500 papers listed in the journal Linguistics Abstracts were in English. In computer science, the proportion is even higher.

Another example is the development of computer software and the number of sites on the internet written in English. According to Robertson andScholte (2007:714) 68 per cent of Web pages were in English in 2004. This figure is huge when compared with sites in Japanese ( 7 per cent), German ( 6 per cent), Chinese (4 per cent), or French (3 per cent). It clearly shows that not all the users who visit Web sites in English are native speakers, which is an additional indication of the role played by English as a world language, shaping a distinct cultural aspect of contemporary society.

Another key feature related to current globalization is the advent of numerous advanced technological breakthroughs and devices for commuting information and data worldwide. Certainly, this issue is strongly related to its recent wave.The same assumption applies to the debate involving law, nation-state and culture. This does not mean that in ancient age these aspects were unimportant, but changes in these areas at that time were much lengthier, and would require a long explanation (see for example Vlassopoulos 2007).For this reason, the analysis below will focus on discussing the importance of the sefeatures in contemporary period.

Over the past three decades, deep transformations in information and communication technologies (ICTs) have gained momentum. They have changed the nature of human interaction, affecting corporations, governments, institutions, cross-country cultural differences and the everyday life of ordinary people. One of the major achievements of this revolution is that these technological innovations have created an enormous potential for transmission of information in real time and at unprecedented speed, reaching areas of the world hitherto considered remote.

Indeed, the most remarkable technological progresses of the 20th century were the developments in ICTs. Significant technologies created in both areas, respectively, were communication via satellites and fibre optic cables (including submarine cables), and the development of computer-based information systems (chiefly software applications and computer hardware). The Internet was one of most successful results of the interaction between telecommunications and computation, so that nowadays it is virtually impossible to expand the development of telecommunications without computational support.

These technologies have allowed the traffic of a great amount of data (based on the exponential capacity of fibre optics), covering continental distances through the use of satellites. As is well-known, there are other technologies of data transmission based on copper wires and broadcasting, but the amount of information they once transmitted and the range of these transmissions cannot be compared with the performance of the satellite and optical fibre.

Certainly, an isolated change does not make a revolution. Rather, these new technologies have interacted with each other and developed in parallel to the digital revolution. 
The digital revolution is sweeping all analogue media before it, allowing unparalleled success in long distance data transmission. Digital communication works by converting electronic signals (data, voice, music) into digital (binary) code. Digital data transmission can be broadcast through fibre optics and satellites, controlled by computers. This technology vastly reduces the potential for signal corruption during transmission by weather conditions, and other problems that can interfere with the quality of reception. As a result, the volume of information exchanged is not only much greater than the analogue system but is also much more reliable. The technological advances resulting from ICT devices have been making use of digital technology (and vice versa) and providing a massive exchange of data transmission worldwide.

Internet, satellites, computer systems and fibre optics revolutionise modern telecommunications, providing a high-quality and low-cost service of data transmission for users who have access to the sophisticated equipment. Companies, banks, central banks, stock markets and households can interact electronically at any time, twenty four hours a day, seven days a week, carrying out a wide variety of productive, commercial and financial activities.

The payoffs from such breakthroughs have been enormous. By satellite, data transmission between telephones and computers is almost instantaneous in virtually any part of the world, and as a result the use of these technologies in productive, commercial and financial activities has been extensive. But there is a crucial difference between the uses of these technologies in such activities. The nature of financial activity does not involve the same formal and bureaucratic proceedings as commercial ones. That means that the time to conclude a transaction is the key determinant variable that differentiates both activities. The time required to conclude a financial deal is much less than what is necessary in a commercial transaction. Consequently, the time of re-contraction is also much less. In this way, applications of ICT in finance and accounting have been encouraging better processing and easier dissemination of information than in other globalised activities, so one can conclude that its potential to increase is higher.

Technological developments have become increasingly enmeshed in contemporary society, and have been affecting a wide range of areas, from medicine to sports, from culture to finance. Progress in this field has made a profound impact on global integration, both positive and negative since ambiguities are inherent in any process of technological change. Nevertheless, it is worth emphasising that technology is not a panacea or a "free lunch", and it is also not capable of bringing the world to Utopia. As a matter of fact, ICTs are distributed unevenly worldwide. More recently, prompted by the uneven geographical diffusion of ICTs and the Internet, multilateral institutions such as the UN, the World Bank and the OECD have turned their attention to the inequalities of access to information. This is the well-known topic of Digital Divide.

The problem promoted by the digital divide is not only geographical but social (DiMaggio et al., 2004). Technology per se is one important dimension of globalization but it has 
neither an even worldwide spread nor the capacity to eliminate social inequalities. Conversely, it has been widening the gap between rich and poor nations. Hence, reducing the digital divide is often considered as a major political matter in the world (digital) economy.

Changes in international law have also played an important role in the current process of globalization. This dimension can be seen through the development of multilateral agreements in a variety of areas such as trade, finance, human rights, property rights, international crime, environment, terrorism, money laundering, etc. From the end of WWII to the 1960s, these issues had mostly lain within domestic jurisdiction, i.e. domestic states were dealing with some of these issues isolatedly. However, the idea of nation-state sovereignty has greatly changed since those days.

The erosion of nation-state autonomy, especially in the wake of the 1990s liberalisation era, has transformed international law from the "law of the state" to the "law of the international community". The increased international connectivity in various areas, (including especially the rapid growth of internet business) has also brought to light a variety of legal issues that have been solved through adjustments in the former established legal apparatus. In other words, most of the aforementioned prominent legal matters such as international trade, finance, human rights, business crime and terrorism are no longer domestic concerns, but concerns of the international community.

These changes have urged the necessity to codify some rules to deal with a variety of problems raised. These rules have been addressed by the establishment of new regulations, codes, international conventions and multilateral agreements to adapt previous international law in order to deal with the new judicial status quo. The absence of international regulation and multilateral agreements in the light of these developments could lead the global society to a chaotic state. All these procedures, put into operation by legal institutions, are an indication of the striking transformations caused by the recent surge of globalization.

Even recognising that the state's abilities for governance have changed and weakened considerably during the last few decades, non-mainstream scholars believe that the role of the nation-states remains pivotal in providing legitimacy for supra-national and sub-national governance mechanisms. According to them, the pressure coming from international financial markets has changed the scope of the domestic political economy but it has not eliminated the autonomy of nation-states. Even agreeing that governments have lost some degree of manoeuvrability to manage their economic policies during periods of high capital integration (past and present), the aforementioned authors sustain that this does not mean the end of nation-states and the absence of political alternatives against the process of economic policy homogenisation (see Chang 2002a, 2002b, 2011, Chang andGrabel 2004-5). In other words, domestic financial systems are still regulated and managed by public policies, although the political and economic power of nation-states may vary over time from country to country. 
To summarize this aspect related to the globalization of politics, in comparison to the earlier periods of capitalist era, governments have less autonomy to operate their economic policies. However,now there is not absolute loss of control over them.According to the scholars above, global markets do not eliminate global inequalities and, as a result, additional public policies are necessary to bridge this gap. Furthermore, in order to deal with those problems, many other instruments must be taken into account by nation-states (and/or by global institutions) such as adequate disclosure practices, prudential guidelines on controlling risk and restructuring the advances of financial institutions, and the development of institutions that fight against corruption and money laundering. This is the alleged new historical role of the state.

Culture is another dimension that has been changing considerably under the current globalization. This aspect is closely related to the emergence and global spread of the Internet. The World Wide Web (www) has changed the lifestyle and working environment of people all over the world. Communication through the internet has been an icon of global integration. Not only for searching and exchanging information but also through the use of internet telephony provided by companies such as Skype, Google Talk, Yahoo! Messenger and MSN Messenger, to mention only the most well-known enterprises.Presently, there are still dozens of online social networking services through which people around the world interact in different ways in real time. The most notorious examples of this wave of sharing on the Internet are the advent of Facebook, Google+, Twitter and WhatsApp.

Mostly spurred by the rapid progress in commuting information, globalization has been promoting greater worldwide cultural exchange in various aspects.For instance, it can be seen in music of all types, in science, art, religion, politics, etc.In this sense, an important question to be made is: how to measure the role played by social media in current days? Besides strengthening communication and exchange of information globally, it has been alsospreading social and political values to different cultures worldwide. In fact, it has beenone of the elements that contributed to speed up political changes, especially in the 2010 wave of protests that became known as the Arab Spring. On this account, it was used (primarily among the youth) to arrange meetings in TahrirSquare in Egypt in 2011, during the protests against the dictatorship of former president Hosni Mubarak.The use of social media were important in organizing protests, strikes, and marches in many Arab countries that were involved in the wave of complains motivated by all kinds of dissatisfactions with local governments.It also gained notoriety more recently from the work of blogger Yoani Sánchezin digital journalism.

Still in relation to the cultural changes promoted by globalization, it may be mentioned that multi-national companies and credit institutions took advantage of decreasing state regulations in different sectors to develop a variety of strategies (joint ventures, mergers, acquisitions, inter-firm alliances, subcontracting arrangements, outsourcing, new financial products, etc) to overcome national frontiers. Their key purpose is to reach remote and 
wide markets. Accordingly, over the past few decades, these corporations have significantly increased their ability to operate in different cultures and transcend ethnic divisions in order to achieve their investment goals on a global scale.

\section{Concluding remarks}

This article has displayed an unconventional interpretation of globalization in historical perspective. It acknowledges the existence of various historical episodes of globalization throughout the centuries of human interaction. The phenomenon is understood as a systematic series of changes that moves social relations from the regional to the transcontinental (or interregional) level. This process changes human organisation, shapes new institutions, and affects at least the seven aspects mentioned in Table 1 above, i.e. economic, political, cultural, military and environmental. In this sense, globalization has evolved in different historical forms, multiple causes, and multiple equilibria.

It is recognised that globalization is not just an economic matter, but a confluence of factors interpreted in a historical perspective which results in significant transformations of different globalization regimes that have occurred since ancient times. To reach this conclusion, the article started addressing scholarly contributions of economists and other social scientists on key aspects of the globalisation debate, intending to gain a better understanding of the core concepts and theories involved. After displaying the overall picture on the preconditions of globalisation, it dealt with the debate on globalisation chronology. The main purpose of this section is to propose an unconventional approach to the historic evolution of globalization. From a multidisciplinary perspective, it was concluded that this is an age-old phenomenon, not only from the last few decades (or centuries). Globalization is not just an economic matter, but a confluence of transformations in social context. Therefore, the following section dealt with its core dimensions outside economics, such as, language, technology, law and nation-state.

The article has addressed key issues such as its preconditions, periodization and some of its dimensions outside economics. Despite the effort to present a concise and wide picture of the theme, this survey looks to bring together key historical elements in order to examine a phenomenon that marked various eras of humankind.

\footnotetext{
Abstract

Unlike the short-term business cycles,globalization has developed in long waves surrounded by periods of booms and different types of crises. The phenomenon is usually associated with a process of the integration of national economies into a wider (global) sphere involving productive and financial markets. The current increased use of the term does not mean that the phenomenon is actually new. Hence, the article aims to analyse preconditions, periodization and dimensions of globalization in historical perspective. Many scholars have discussed its causes and consequences based on what has taken place in the last few decades, normally starting in the late 1970s. Never-
} 
138 An unconventional interpretation on periodization and dimensions of globalization in historical perspective

theless, the phenomenon has precedents in history, which means, it is not an exclusive occurrence of the capitalism of the late 20th century. A literature has flourished suggesting that the occurrence of greater global connectivity involving many areas of human activity and social interaction has occurred at times in history since a century (or even centuries) ago. So, the article postulates that globalization is not only secular but an ancient phenomenon. Therefore,proposes that noneconomic aspects of global integration should be considered as key elements to survey the topic, which have been neglected by economists and economic historians. It concludes that the beginning of the first historical occurrences of globalization occurred much as early as in the Middle Ages, and emphasises the importance of aspects of it outside economics, such as culture and language.

Keywords: globalization eras, history, culture and language

JEL: F00; O10; O47

\section{References}

ALEXANDRE, S. Contemporary Financial Globalisation in Historical Perspective: Dimensions, Preconditions and Consequences of the Recent and Unprecedented Surge in Global Financial Activity. Tese (Doutorado), 2008.

BORDO, M. Globalization in historical perspective. Business Economics, p. 20-9, 2002.

BORDO, M. D.; EICHENGREEN, B.; IRWIN, D. A. Is globalization today really different than globalization a hunderd years ago? 1999.

BORDO, M. D.; EICHENGREEN, B.; KIM, J. Was there really an earlier period of international financial integration comparable to today? 1998.

BORDO, M. D.; ROCKOFF, H. The gold standard as a "good housekeeping seal of approval". The Journal of Economic History, Cambridge University Press, v. 56, n. 2, p. 389-428, 1996.

CHANG, H.-J. Breaking the mould: an institutionalist political economy alternative to the neo-liberal theory of the market and the state. Cambridge Journal of Economics, Oxford University Press, v. 26, n. 5, p. 539-559, 2002.

CHANG, H.-J. Kicking away the ladder: development strategy in historical perspective. [S.1.]: Anthem Press, 2002b. 187 p.

CHANG, H.-J. Institutions and economic development: theory, policy and history. Journal of Institutional Economics, Cambridge University Press, v. 7, n. 4, p. 1-26, 2011.

Econômica-Niterói, v. 21, n. 1, p. 121-140. Junho, 2019 
CHANG, H.-J.; GRABEL, I. Reclaiming development from the washington consensus. Journal of Post Keynesian Economics, Taylor \& Francis, v. 27, n. 2, p. 273-291, 2004.

CHANG, H.-J.; GRABEL, I. Reclaiming development from the washington consensus. Journal of Post Keynesian Economics, Winter, v. 27, n. (2), p. 273-91, 2011.

COMMUNICATIONS Outlook 2001. <www.oecd.org/sti/telecom/outlook>.

DIMAGGIO, P. et al. Globalism and localism: What are the limits of competition and security? Fernando Braudel Institute of World Economy, Braudel Papers, p. 3-6, 1997.

DIMAGGIO, P. et al. Digital inequality: From unequal access to differentiated use. In: Social inequality. [S.1.]: Russell Sage Foundation, 2004. p. 355-400.

EICHENGREEN, B.; BORDO, M. D. Crises now and then: What lessons from the last era of financial globalization. [S.1.], 2002.

GIDDENS, A. Runaway world: How globalisation is shaping our lives. london: Profile. p. 104, 2002.

GIDDENS, A. Sociology. 5. ed. [S.1.: s.n.], 2002.

HELD, D.; GUIBERNAU, M. Globalization, cosmopolitanism, and democracy: an interview with david held. Constellations, Blackwell Publishers, v. 8, n. 4, p. 427-441, 2001.

HELD, D. et al. Global transformations: Politics, economics and culture. In: Politics at the Edge. [S.1.]: Springer, 2000. p. 14-28.

JONES, R. B.; DUVALL, R. Routledge encyclopedia of international political economy. Routledge: London and New York., Interconnectedness, 2001.

KEOHANE, R. O.; NYE, J. S. Globalization: What's new? what's not?(and so what?). FOREIGN POLICY-WASHINGTON-, Foreign Policy, p. 104-119, 2000.

KLEIN, N. The shock doctrine: The rise of disaster capitalism. [S.1.]: Macmillan, 2007.

KREGEL, J. Capital flows: Globalization of production and financing development. UNCTAD review, p. 23-38, 1994.

MEADOWS, P. Culture theory and industrial analysis. The Annals of the American Academy of Political and Social Science, Sage Publications Sage CA: Thousand Oaks, CA, v. 274, n. 1, p. 9-16, 1951.

O'ROURKE, K. H.; WILLIAMSON, J. G. When did globalisation begin? European Review of Economic History, Cambridge University Press, v. 6, n. 1, p. 23-50, 2002. 
140 An unconventional interpretation on periodization and dimensions of globalization in historical perspective

PERRATON, J. The scope and implications of globalization. Michie, Jonathan (ed) The Handbook of Globalization, Cheltenham. Edward Elgar, p. 37-60, 2003.

ROBERTSON, R.; SCHOLTE, J. A. Encyclopedia of globalization. New York, Routledge, 2007.

SCHOLTE, A. J. Globalization: a critical introduction. New York: Palgrave, 2000.

SCHOLTE, A. J. Globalization. JONES, R. J. Barry (ed). Routledge Encyclopedia of International Political Economy, London and New York, 2001.

SCHOLTE, A. J. hat is globalization? the definitional issue - again. Centre for the Study of Globalization and Regionalisation, p. 1-34, 2002.

STIGLITZ, J. E. Globalization and its discontents. NewYork, W. W. Norton and Company, p. 282, 2002.

VLASSOPOULOS, K. Unthinking the Greek polis: Ancient Greek history beyond eurocentrism. [S.1.]: Cambridge University Press, 2007.

Recebido em 04 de abril de 2018. Aceito para publicação em 27 de novembro de 2018. 